Supplement of Earth Syst. Sci. Data, 13, 343-356, 2021

https://doi.org/10.5194/essd-13-343-2021-supplement

(c) Author(s) 2021. This work is distributed under

the Creative Commons Attribution 4.0 License.

(c) (1)

Supplement of

\title{
Database of global glendonite and ikaite records throughout the Phanerozoic
}

Mikhail Rogov et al.

Correspondence to: Mikhail Rogov (russianjurassic@gmail.com)

The copyright of individual parts of the supplement might differ from the CC BY 4.0 License. 


\section{Supplementary}

\section{List of terms used in online search for glendonites}

Anthraconite (Anthrakonit, антраконит). This term is also frequently using for any black limestone bands or concretions (see Berg-Madsen, 1989 for review), but in some cases (i.e. Early Paleozoic of Estonia and Saint-Petersburg area) this term

5 was applied solely for glendonites for $\sim 150$ years (Hausmann, 1806: introduction of the term 'Anthraconite' for black limestones; Karpinsky, 1887: first usage of this term for Ordovician glendonites)

Barleycorn

Fundylite (Steacy, Grant, 1974)

Gaylussite (гейлюссит)

10 Gennoishi (玄能石, геннойши) (Ко, 1896)

Gerstenkörner

Glendonite (глендонит) (David et al., 1905)

Hedgehogs (Fricker, 1963)

Hokou-seki (方孔石)

15 Ikaite (Pauly, 1963)

Jarrowite (Browell, 1863)

Polar euhedrons (Kemper, Schmitz, 1975)

Pseudogaylussite (псевдогейлюссит) (van Calker, 1897)

Stellate (calcareous) concretions (звёздчатые конкреции)

20 Thinolite (King, 1878)

Беломорские рогульки (White sea hornlets: Jeremejew, 1882), беломорское ископаемое (White sea fossil: Sokolov, 1825)

\section{List of online search engines and alerts used for data collecting in this study}

25 http://goolge.com (mainly with search for pdfs, by using Boolean search filetype:pdf)

http://books.google.com (search through different books and periodicals, including those which available in snippet view mode only)

http://scholar.google.com (search through papers and set up alerts for new publications containing words 'glendonite' and/or 'ikaite')

30 http://scopus.com (search through papers and set up alerts for new publications containing words 'glendonite' and/or 'ikaite')

http://app.dimensions.ai (keyword search) 
http://apps.webofknowledge.com (keyword search)

https://ci.nii.ac.jp/en/ ; https://www.jstage.jst.go.jp/ (search for Japanese papers)

35 http://archive.org (full-text keyword search)

http://gallica.bnf.fr (full-text keyword search)

\section{References}

Berg-Madsen, V.: Origin and usage of the geological terms orsten, stinkstone, and anthraconite, Arch. Nat. Hist., 16(2), 191-

208, doi:10.3366/anh.1989.16.2.191, 1989.

Browell, E. J. J.: Description and analysis of an undescribed mineral from Jarrow Slake, Transactions of the Tyneside Naturalists Field Club, 5, 103-104, 1863.

van Calker, F. V.: Beitrag zur Kenntnis des Pseudogaylussit, und über dessen Vorkommen in Holland, Zeitschrift für Krystallographie, Mineralogie und Geologie, 28(6), 556-572, doi: 10.1524/zkri.1897.28.1.556, 1897.

45 David, T. W. E., Taylor, T. G., Woolnough, W. G. and Foxall, H. G.: Occurrence of the pseudomorph glendonites in New South Wales, Records of the Geological Survey of New South Wales, 8, 162-179, 1905.

Fricker, P.E.: Geology of the expedition area. Western Central Axel Heiberg Island, Canadian Arctic Archipelago. Axel Heiberg Island research report. McGill University, Montreal. Jacobsen-McGill Arctic Research Expedition 1959-1962. Geology, No. 1, 156 pp., 1963.

50 Hausmann, J. F. L.: Correspondenz-Nachrichten, Efemeriden der Berg- und Hüttenkunde, 2, 303-305, 1806.

Jeremejew, P.: Die pseudomorphen Krystalle des Aragonite and des Eisen-oxydes ans den russischen Fundorten, Verhandlungen der Russisch-kaiserlichen mineralogischen Gesellschaft zu St. Petersburg, 2(17), 319-336, 1882. (in Russian)

Karpinsky, A.: Ueber die cambrische, silurische und einige andere Ablagerungen in Gouwernement Pskow, Mining journal

(Gorny zhurnal), 2, 261-270, 1887. (in Russian)

Kemper, E. and Schmitz, H. H.: Stellate nodules from the upper Deer Bay formation (Valanginian) of Arctic Canada, Geological Survey of Canada Paper, 75, 109-119, doi: 10.4095/103040, 1975.

King, C.: Report of the Geological Exploration of the Fortieth Parallel, Volume I: Systematic Geology, Professional papers of the Engeneer department US army, 761 pp., 1878.

60 Ko, S.: Mineral localities in Chiisagata, Shinano, Jour. Geol. Soc. Japan, 3(34), 321-323, doi:10.5575/geosoc.3.34_321, 1896.

Pauly, H.: "Ikaite", a new mineral from Greenland, Arctic, 16(4), 263-264, doi: 10.14430/arctic3545, 1963.

Sokolov, D.: On White Sea mineral, Mining journal (Gorny zhurnal), 6, 117-120, 1825. (in Russian) 
Steacy, H. R. and Grant, D. R.: Tidal muds reveal mineral curiosity, Can. Geogr., 88(1), 36-38, 1974. 